\title{
Helminthic Infestation of Grass Root Level Students in a Selected Madrasha of Bangladesh
}

${ }^{*}$ Habib RB ${ }^{1}$, Kabir $\mathrm{ARML}^{2}$, Rouf MA ${ }^{3}$, Ullah MSS ${ }^{4}$, Hossain $\mathrm{MN}^{5}$, Rahman $\mathrm{MN}^{6}$, Boyan RK ${ }^{7}$, Hye MA ${ }^{8}$, Khan $\mathrm{MKA}^{9}$, Roy $\mathrm{S}^{10}$, Haque $\mathrm{MR}^{11}$, Jamil JI ${ }^{12}$

\begin{abstract}
In Bangladesh, 4 million students study in 64000 madrasha, which represent $7 \%$ of all students, most of these are unregistered. There is little evaluation of helminthic infestation by any authority. It is believed that madrasha students came from vulnerable part of society. : Present Sheikh Hasian government declared on equivalency of their certificate therefore it is important to study on them and evaluate their helminthic infestation. May be this is one of the first study on helminthic infestation on grass root level madrasha students in Bangladesh. We conducted the study to evaluate on
\end{abstract}

1. *Dr. Rahat Bin Habib, Research Assistant, Department of Pediatrics, Sir Salimullah Medical Collage and Mitford Hospital, Dhaka. Email-ssmcdmc@gmail.com

2. Dr. A.R.M.LuthfulKabir, Professor of Pediatrics, Ad-din Medical Collage Hospital, Dhaka

3. Dr. Md Abdur Rouf, Professor of Pediatrics, Sir Salimullah Medical Collage and Mitford Hospita, Dhaka

4. Dr. Md. Sk. Shahid Ullah, Professor and Head, Department of Microbiology, Ad-din Sakina Medical Collage, Joshore.

5. Dr. Md. Nazmul Hossain, Associate Professor, Department of Pediatrics, Institute of Child and Mother Helath (ICMH), Dhaka.

6. Dr. Md. Anisur Rahman, Assistant Professor, Department of Pediatrics, SSMC and Mitford Hospital, Dhaka.

7. Dr. Rushdul Karim Boyan, Associate Professor, Department of Pediatrics, Mymensing Medical Collage, Bangladesh.

8. Dr. Md. Abdul Hye, Assistant Professor, Department of Pediatrics, Joshore Medical Collage, Bangladesh.

9. Dr. Md. Kamrul Ahsan Khan, Assistant Professor (Neonatology), Sheikh Sayera Khatun Medical Collage, Gopalganj.

10. Dr. Sudipta Roy, Assistant Professor, Department of Pediatrics, Ad-din Women's Medical Collage and Hospital, Dhaka.

11. Dr. Mohammad Rezaul Haque, Associate Professor, Department of Pediatrics, Institute of Child and Mother Health (ICMH), Dhaka.

12. Dr. Joheb Imtiaz Jamil, Assistant Professor, Department of Pediatrics, Institute of Child and Mother Health (ICMH), Dhaka

*For correcpondence helminthiasis to find out current situations, to identify the risk factors and for intervention to control of helminthic infestation. This cross sectional study was conducted on 164 from 1000 residential students by simple random sampling. Face to face interview and anthropometric measurement were conducted by semistructured open ended questionnaire from those students. Out of hundred-sixty four students all were male, age range from 06-18 years, ova found $75 \%$ students in their stool sample, $71 \%$ have multiple helminthasis, Ascaris Lumbricoids (AL) was the most (28\%) prevalence, in polyparasitism 58\% were Ascaris Lumbricoids and Trichuris Trichuria $(A L+T T)$, anal itching found $68 \%$ students which indicate pin worm, no antihelminthic intake $76 \%$ students within 6 months. Teachers and parent's health education help to prevent helminthasis. Regular survey, evaluation is needed to identify the risk factors of helminthasis for intervention, monitoring, guidance and training of students and teachers to improve their personal hygiene practice. Moreover need to intake of regular antihelminthic for dewarming to build a healthy green Bangladesh.

Keywords: Helminthasis, Madrasha students.

\section{INTRODUCTION}

Madrasha is faith based religious school. In Bangladesh there are 20808 registered madrasha. Its believe that there are total 64000 madrashas which are not controlled by any authority. ${ }^{1}$

In Bangladesh, parasitic infestation is also a major public health problem both in rural and urban area. Low socioeconomic condition, low living condition, poor hygienic practices with unhygienic surroundings, lack of sanitary latrine and most important is lack of health education are the reasons behind this. Their personal hyegine practice is poor and they are not regular intake of antihelminthic. $^{2}$

Helminthasis ranks as the $4^{\text {th }}$ case after the big three 1 ) Respiratory tract infection 2) Diarrhoea 3) Malnutrition in causing severe degree of morbidity and mortality in infants and children in Bangladesh. ${ }^{3}$ 
Helminthic infection due to nematode is a major public health hazard of widespread epidemicity in various parts of the world. Multiple infestation of two or more of these nematodes eg. Ascaris lumbricoides (AL), Hookworm (AD), Necato americanas (NA), Enterobius vermicularis (EV) and Trichuris trichiura (TT) are also very common in these countries. ${ }^{4}$

About $61 \%$ population live in rural area. The temperature, humidity, soil characteristics, water source and socio-economic condition all are suitable environmental factors for parasitic infestation in this country. ${ }^{5}$ According to a natural survey Roundworm in rural children was found to be $92.21 \%$ and urban children $27.61 \%{ }^{6}$

People of Bangladesh are fighting againsed poverty, hungry, illiteracy and yearly natural disaster like flood, cyclone- the effect of parasitic infestation on our productive age. Rather then antihelminthic alone for reducing the helminthes infestations, more emphasis is now given on preventive and control measures. With the improvement of sanitation and living standard, prevalence of parasitic infestation is decreased in developed countries. South Korea may example of this. Here in 1971, the prevalence of Ascaris lumbricoides was 54.9\% and in 1985 it comes down to $13 \%$ in nation wide and only $2.3 \%$ in students group. So, it resumes that, in spite of being endemic, intestinal parasites are controllable if personal hyegiene is practiced in daily life. ${ }^{7}$

Because of lack of sanitation, unhygienic surrounding and lack of health education the children residing in slum and rural area suffer most. It has been observed from various studies in Bangladesh that 36-85\% children suffers from Roundworm, 2-53\% from Hookworm and 10-53\% from Whipworm. ${ }^{8}$ This study was to identify helinthic infestation of grass root level students in a selected madrasha.

\section{MATERIALS AND METHOD}

This descriptive type of cross sectional study was designed to assess of helminthic infestation conducted in convenience selected madrasha in Narayanganj, Bangladesh during March to August 2016. The target population (1000) consisted of individuals living and studying in that madrasha in Arihazar, Narayanganj. A total of 164 students were enrolled for the study by simple random sampling. Sample size was calculated according to $\mathrm{n}=\mathrm{Z}^{2} \mathrm{pq} / \mathrm{d}^{2}$. An open semistructured questionnaire and a chaque list was used to collect data from face to face interview and stool sample was collected from madrasha and preserved by formalin in a container individually and examination by routine microscopic examination in a microbiological laboratory (Shuvechhe General Hospital in Narayanganj). Information regarding the structure of madrasha, source of drinking water, knowledge about activities of personal hygiene and parents education were collected from each. Verbal informed consent was taken from the respondents by explaining the purpose of the study. Collected data were analysed by SPSS (Statistical Package of Social Science), Excel and Windows software programme.

The study was approved by the ethical board of the Bangladesh Society of Epidemiology (BSE).

\section{RESULTS}

Table-I: Distribution of students by Helminthiasis

\begin{tabular}{|c|c|c|}
\hline Helminthasis & Catagory & Frequency \\
\hline \multirow[t]{2}{*}{ Ova } & Present & $123(75)$ \\
\hline & Absent & $41(25)$ \\
\hline \multirow[t]{2}{*}{$\begin{array}{l}\text { Helminthic } \\
\text { infestation }\end{array}$} & $\begin{array}{l}\text { Single helminthic } \\
\text { infestation }\end{array}$ & $36(29)$ \\
\hline & $\begin{array}{c}\text { Multiple helminthic } \\
\text { infestation }\end{array}$ & $87(71)$ \\
\hline \multirow[t]{4}{*}{ Single Helminthiasis } & $\mathrm{AL}$ & $35(28)$ \\
\hline & TT & $01(01)$ \\
\hline & $\mathrm{Hw}$ & 00 \\
\hline & SS & 00 \\
\hline \multirow[t]{5}{*}{ Polyparasitism } & $\mathrm{AL}+\mathrm{TT}$ & $71(58)$ \\
\hline & $\mathrm{AL}+\mathrm{Hw}$ & $01(01)$ \\
\hline & $\mathrm{AL}+\mathrm{Hw}+\mathrm{TT}$ & $05(04)$ \\
\hline & $\mathrm{SS}+\mathrm{AL}$ & $04(03)$ \\
\hline & $S S+A L+T T$ & $06(05)$ \\
\hline \multirow[t]{2}{*}{ Itching anus } & Presents & $110(67)$ \\
\hline & Absents & $54(33)$ \\
\hline
\end{tabular}

Out of 164 students, ova found in 123 (75\%) samples after routine microscopic examination of stool in microbiological laboratory. Among them near to one third (29 \%) suffered from single and more then two third (71\%) from multiple helminthic infestations.

AL was the most positive one (28\%), $2^{\text {nd }}$ one was TT and 36 students suffered by single helminthic infestation of 123 samples. In case of polyparasitism, most were, 71 (58\%) suffered from AL+TT, $2^{\text {nd }}$ prevalence were $05 \%$ $(\mathrm{SS}+\mathrm{AL}+\mathrm{TT})$, then $\mathrm{AL}+\mathrm{Hw}+\mathrm{TT}$ were $04 \%$. Among all students, $67 \%(\mathrm{n}=110)$ had history of regular anal itching. 


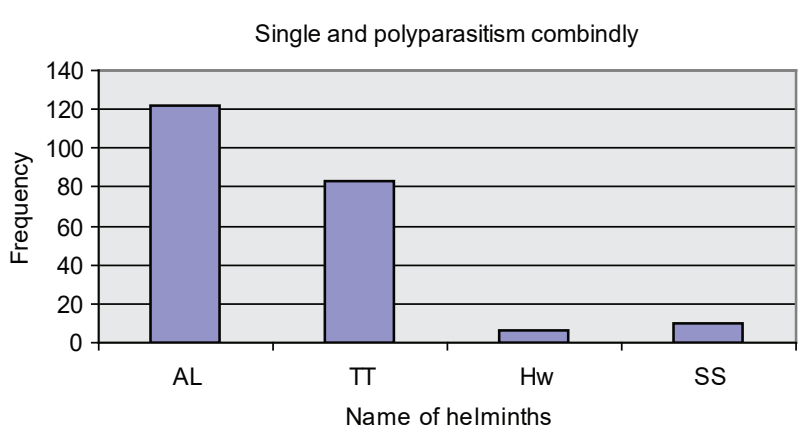

Figure-1: Frequency of single and polyparasitism combindly

Distribution of students by common helminthic infestation (Single and polyparasitism).

Almost three quarter, 74\% $(n=122)$ students suffered by AL, more then half (51\%) suffered from TT, Hw was 06 $(04 \%)$ and SS was $10(06 \%)$,

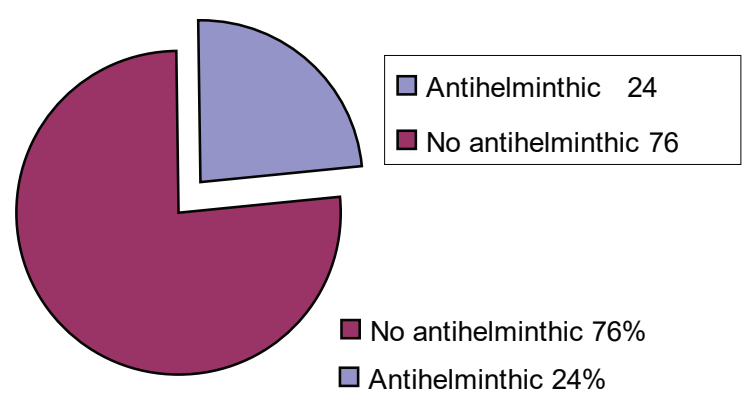

Figure-2: Distribution of students by antihelminthic intake within 6 months

Most of students, $76 \%(n=124)$ there were no history of taken antihelminthic within 06 months.

Table-II : Non parametric analysis $(\mathrm{n}=124)$

\begin{tabular}{|ll|l|l|l|}
\hline \multicolumn{2}{|l|}{ Education of parents } & \multicolumn{2}{|c|}{ Ova } & Total \\
\hline & & Present & Absent & \\
\hline $\begin{array}{l}\text { Primary } \\
\text { to high }\end{array}$ & Observed & $48(29 \%)$ & $24(15 \%)$ & $72(44 \%)$ \\
\hline Illiterate & Observed & $75(46 \%)$ & $17(10 \%)$ & $92(56 \%)$ \\
\hline Total & Observed & $123(75 \%)$ & $41(25 \%)$ & $164(100 \%)$ \\
\hline
\end{tabular}

$\mathrm{X} 25.546 \mathrm{df}=1 \quad \mathrm{P}<0.05$

According to primary to higher education level of parents, ova found in $29 \%$ stool samples and $46 \%$ ova present whose parents were illiterate. It indicate parent's education and helminthic infestation were correlated. Parent's education help to reduce helminthic infestation.

\section{DISCUSSION}

In this cross sectional study, after routine microscopic examination ova was found in stool of $123(75 \%)$ samples among 164 students. Near to one third (29\%) suffered from single and more then two third (71\%) from multiple helminthic infestations. (Table-1) It is more then usual picture, which indicate poor personal hyegine practice and not regular intake of antihelminthic drug. $75 \%$ of students have helminthic infestation with the types Ascaris lumbricoides, Hookworm, Trichuris trichuria and Stongyloides stercoralis (Table-1). In single infestation there are 29\% (AL-28\%, TT-1\%) (Table-1) and polyparasitism 71\% (AL+TT-58\%, AL+ Hw-1\%, AL+Hw+TT-4\%, SS+AL-3\%, AL+TT+SS-5\%) (Table-I) In a study he incidence of helminthasis different areas of Dhaka city showed that in children of 1-5 years age group were $21 \%$, Hw 5\%, TT-6\%, EH-1\%, EV-0.1\% and multiple 10.4\% 9 . In this study there were $82 \%$ helminthasis in $13-18$ year age group, 67\% in 6-12 year groups (Table-II) which shows correlation $(\mathrm{p}<0.05)$ between helminthiasis and different age group of students. According to comparatively higher education level of parents, ova found in $29 \%$ of stool samples and $46 \%$ ova present in their stool samples whose parents were illiterate. It indicate parents education and helminthic infestation were correlated in the non parametric analysis $\mathrm{P}<0.05$ (Table-2). It indicate education act as reducing factor for decline helminthasis. AL was the most positive one $(28 \%), 2^{\text {nd }}$ one was TT and 36 students suffered by single helminthic infestation among 123 samples (Table-1). Prevalence of AL was the highest and it may be one of the cause of undernutrition and maldigestion of children.

In case of polyparasitism, most were, 71 (58\%) suffered from AL+TT, $2^{\text {nd }}$ prevalence were $05 \%(\mathrm{SS}+\mathrm{AL}+\mathrm{TT})$, then $\mathrm{AL}+\mathrm{Hw}+\mathrm{TT}$ were $04 \%$ (Table-1).

Among all of them, 67\% ( $n=110)$ had history of regular anal itching. Itching anus indicate pinworm present in GIT and it is an important risk factor for hand to mouth spread of ova and organism and this type of practice is one of the reason for helminthic prevalence and disease spread. This study correlate with in research paper where 92\% people with anal itching related with pin worm infestation. ${ }^{9,10}$

Here most of students, $76 \%(n=124)$ there were no history of taken antihelminthic within 06 months (Pie chart-2). It is dissimilar of a report from Bangladesh health bulletin, here Bangladesh government provide antihelminthic to all children every 6 months interval and encourage to all adult to intake antihelminthic every 6 months interval. ${ }^{10}$ 


\section{CONCLUSIONS}

There need more and regular survey, evaluation to identify the risk factors of helminthasis for intervention, monitoring, guidance and training of students and teachers to improve their personal hygiene practice and intake of regular antihelminthic for dewarming to build a healthy green Bangladesh.

\section{REFERENCE}

1. Madrasha study from Wikipedia. 2018

2. Haq. Farid, Hamid AA, A Sarwar, M Asaduzzaman M \& Y Mahfudq Y: BMRC bulletin. 2001. June (8): 1-6

3. Nazer F H. Common helminthic problem in pediatrics and there management: Sylhet2006. January (5): 23-27
4. Statistical pocket book 2001. P: 54-62

5. Bangladesh Demographic profile, 2018

6. Mutallib M A, Islam N, Islam S, Prevellence of intestinal parasites in rural children in June 1992; 67-72.

7. Seo B S and Chai J Y. Status analysis of Trichuriasis in Korea and a pilot study on it's treatment and control. Controlled papers on the control of soil transmitted helminthiasis, July 1986; 115-143.

8. IPHN Nutrition Bulletin, Sept.1992, Volume-1: 6

9. Huq NN \& Sheikh Aneena A: Incidence of intestinal parasite in children of different slum. BMA Janu 2004, Volue-17 p 32-38

10. Bangladesh Health Statistics, from Wikipedia.2018 